\title{
Aid and Institution-building: Some Lessons from Indian Agriculture
}

\author{
John Toye
}

\section{Utopia (Limited)}

The follies of aid and technical assistance aimed at institution-building in underdeveloped countries have long been satirised. A century ago, W. S. Gilbert created Zara, the Girton-educated princess of a tiny South Pacific Island, who brought home with her 'six Representatives of the principal causes that have tended to make England the powerful, happy and blameless country which the consensus of European civilisation has declared it to be'. She eagerly advised her father, the King, to 'place yourself unreservedly in the hands of these gentlemen and they will reorganise your country on a footing that will enable you to defy your persecutors'.

The King did so and retribution soon followed in the form of universal discontent. The bitterness and sarcasm with which Gilbert ridiculed the notion of transferring English institutions to distant tropical lands brought retribution down on his head, too. As the public mood of imperialist triumphalism built up in the 1890s, London audiences fell out of love with Gilbert and Sullivan. Utopia (Limited); or the Flowers of Progress failed to amuse. It closed after a short run, rarely to be revived [Wolfson 1976: 147 et passim].

Despite the tradition of satirical attack, the project of transplanting institutions from place to place continues unabashed. In fact, it is easy to replicate institutions in different places; what can sometimes be difficult is to transfer them through time or across cultures. This article looks at one sustained effort at cross-cultural replication of institutions. The area was that of Indian agriculture. The foreign paradigm was the USA rather than England and, fortunately, the results of the effort were rather less unsatisfactory than in Gilbert's forgotten libretto. Nevertheless, elements of comedy were not entirely absent.

\section{Community Development (CD) in the 1950s}

'The average American might ... f feel disgusted with many things in India . . I think you will not feel this way', wrote Pandit Nehru to Dr. Albert C. Mayer on 17 June, 1946 [Thorner 1981: 118]. Mayer combined the technical expertise of an architect and city planner with the same sympathy for Indian villagers that had inspired US missionaries like the Wisers in the 1930s [Wiser and Wiser, 1971]. Having served in India with the US army during the Second World War, his original idea was 'a programme of architectural and physical planning for villages' [Rosen 1985: 49]. This plan was fortunately dropped in favour of a pilot scheme of socioeconomic improvement in rural areas. In 1948, with Nehru's active encouragement, a new type of $\mathrm{CD}$ project was launched in 64 villages of the then United Provinces (the Etawah Project). It was modelled on a more localised version of the "country extension agents' operating in US farming districts in the early twentieth century [Rosen 1985: 82].

In 1949 , the Nationalist cause in mainland China was lost, undermining thereby the long American missionary effort to China. India was seen as the next domino to defend against communism. As Chester Bowles, the US Ambassador to India, put it: 'If we lose India, as we lost China, we shall certainly lose SouthEast Asia with the repercussions running all the way through Africa' [Rosen 1985: 11]. But democracy could, it seemed, defeat communism only if hunger and want were diminished. That was the significance for the US of Etawah. But was this little pilot project replicable?

Paul Hoffman of the Ford Foundation thought it was: 'There is no reason why all 500,000 of India's villages could not make a similar advance' to that of the 64 Etawah villages [Rosen 1985]. Such a statement seemed unremarkable in the messianic and utopian atmosphere of US thinking about foreign aid at this time. For had not the lesson of the Marshall Plan experience been taken to be that the US aid strategy 'must be both global, embracing every part of the world and total, with political, psychological, economic and military considerations integrated into one whole' [Packenham 1973: 42]? 
By 1952, the Government of India (Gol) had decided to build on successes achieved at Etawah - in crop yield per acre, improved technology, road construction and the new institution of the 'village level worker' (VLW) - but, significantly, outside the Ministry of Agriculture, and created a supraministerial coordinating agency, the Community Projects Administration, which between 1956 and 1966 was the separate Ministry of $C D$. Expansion of $C D$ and National Extension Service activities was designed to be dramatically rapid: to cover the entire country by the end of the Second Five-Year Plan.

The trigger for this decision was the ready availability of US government (and private foundation) aid funds. In late 1951, under the Point-4 Technical Assistance Program, the US Congress voted $\$ 50 \mathrm{mn}$ for Indian development. As one commentator has expressed it: 'probably there was no more compelling reason for CD's activation than the availability of external funding and the knowledge that these (government) funds would lapse if not used within a limited amount of time' [Sussman 1982: 85]. Between 1951-52 and 1960-61, the US Government and the Ford Foundation provided more than $\$ 100 \mathrm{mn}$ to finance the CD programme [Brown 1971: 5]. Its isolation from the existing structures administering agriculture was a result of the scepticism expressed by the Ministry of Food and Agriculture about the productivity effects of a changed rural organisation compared with those of raising grain procurement prices [Rosen 1985: 72-3]. The Food Minister, A. P. Jain, warned: 'If the Plan fails, it will wreck on the policy of depressing agricultural prices'. Probably, neither improved incentives for farmers nor organisational changes would have had dramatic results in raising output, given the absence of a new technology to adopt.

The community development programme in India illustrates some classic weaknesses of early aid projects. It was too grandiose. It was undertaken for essentially political reasons, without a proper appraisal of its long-term viability. It grossly underestimated the problems of replicating en masse the successful features of its pilot project which depended critically on high-quality VLWs. Local-level participation was induced by the availability of foreign-financed equipment, rather than by much understanding of, or commitment to, the development objectives of the scheme. Performance was judged in terms of intermediate objectives, such as the rate of expenditure of funds, rather than the final objectives of community development; for instance, over 100 new training centres for VLWs were set up, but only 15 per cent of training time was devoted to agricultural techniques.

These flawed efforts, did, however, leave a legacy of new institutions. Its importance was shown when later agricultural innovations spread fastest and most effectively in those Districts with most prior VLW extension work [Evenson and Kislev, 1976]. When India was subsequently divided into 'development blocks', a new cadre of village-level personnel was in place to carry out government-assigned tasks at the grass roots. Weaknesses remained. The personnel were often poorly trained, weighed down by a multiplicity of tasks (including the distribution of modern inputs), and harassed by representatives of the rural elite. They were organised in a separate structure whose jurisdiction boundaries did not coincide with those of allied public services (irrigation, public works and electricity) [Hopper 1976: 4-5]. The state governments saw $\mathrm{CD}$ blocks as separate entities fed by central government funds and so, contrary to the original intention, concentrated their own funds on non-CD types of spending.

Yet $C D$ had importantly added to rural institutions a prerequisite for new and better development initiatives. It did not resemble the original US 'extension agent model', but that model's promoters - Ensminger and Galbraith - eventually recognised that this was not important, as the model was inappropriate [Rosen 1985: 82].

\section{From Extension to Intensive Development}

With the $C D$ initiative having run its course, and with further Nehru-backed organisational changes in agriculture having been accepted at the Nagpur Congress [1959] but afterwards effectively opposed by key Congress politicians, the development of Indian agriculture needed a new direction. At about this time, expansion of farm output via extension of the cultivated areas was coming up against its limits. The Ford Foundation, in close consultation with the US government, funded experts who prepared (with Indian assistance) a report on the impending 'food crisis' [Gol 1959]. In an attempt to learn from the over-rapid expansion of the $C D$ programme, the report emphasised selectivity, intensity and complementarity. Agricultural inputs were to be concentrated on selected districts, in sufficient quantities, and in the correct proportions: hence, in 1961, the launch of the Intensive Agricultural District Programme. Somewhat better yields were obtained in the IADP districts but the improvement was at first small and patchy.

India's food crisis came to a head in the drought years 1965-66 and 1966-67. In early 1966, the Food Minister, C. Subramanian, spent $\$ 5 \mathrm{mn}$ on 20,000 tonnes of dwarf wheat from Mexico to be used as seed. This, plus massive additions to India's fertiliser supplies, marked the turning point for yields [Hopper 1976: 9; Das gupta 1977: 29], but not until 1968 were the new seeds 
sufficiently widespread to bring about the 'green revolution', the dramatic rises in wheat yields in Punjab, Haryana and Western Uttar Pradesh in 1968-74.

Thus the selective, packaged approach which IADP used to spread the use of modern inputs, building on the block development institutions bequeathed by $\mathrm{CD}$, was in turn not enough by itself to generate rapid rural change. Two other elements were needed: the new seeds and a change in agricultural pricing policy. From the mid-1960s, high wheat prices were used as economic incentives for farmers, to adopt better production practices and to deliver for the government a good part of the increased surplus. The GoI, in the face of political pressure from the rich farmers' lobby, usually pitched its wheat procurement prices above those recommended by the Agricultural Prices Commission in the 1970s, and adoption of the new technology was usually a profitable decision (though perhaps subject to increased risk), especially on the larger farms [Dasgupta 1977: 160-8].

The new 'Mexipak' seeds had originally been developed in Mexico and Pakistan (the Mexican research being financed by the Rockefeller Foundation). But the institutions that could adapt the Mexican seeds to the varied set of agro-climatic environments within India had to be further developed in India. The locational adaptation of the 'miracle seeds' required a network of high-quality agricultural universities and research stations. The Imperial (later Indian) Agricultural Research Institute, Pusa - the IARI - had been set up in 1921 and had soon produced the innovation of the Pusa wheats: India had a basic research endowment. But much more was needed.

As early as 1955 , certain US agricultural experts, acting jointly with Indian counterparts, had reported to the GoI that the CD programme, which concentrated on the wider diffusion and application of existing knowledge of agricultural practices, lacked an important component for success: adequate agricultural research and education. With US aid, the GoI then invited a group of American land-grant universities to establish a number of these around India; five were set up, on the US model, to train agricultural technicians and scientists to provide a flow of improved practices for the VLWs to diffuse. But, because the VLWs never came near to matching the US county extension agent model, particularly in spending so little of their time dealing with agricultural techniques, these institutions never developed vital links with the villages and instead became somewhat isolated and irrelevant.

In addition, in 1956, the Rockefeller Foundation helped to set up a modern postgraduate school at the IARI. Initially, the research effort was concentrated on two main goals: higher maize, sorghum and millet yields (rather than the two major food crops of rice and wheat); and measuring the fertiliser-responsiveness of traditional varieties (rather than developing or adapting highly fertiliser-responsive varieties). Since the 1960s, however, these priorities have been superseded and India has developed an indigenous network of high-quality agricultural universities and research stations, under the supervision of the Indian Council for Agricultural Research: 'There are (in 1983) 32 central research institutes and seven soil conservation research and training institutes... (plus) 21 agricultural universities, 73 agricultural colleges (including those at the agricultural university campuses) and 21 veterinary colleges' [Krueger and Ruttan, 1983: 12-70].

In terms of resources employed and scientific activity, as indicated by published work, the Indian agricultural research community has grown markedly in quantity and quality. The contribution of foreign, particularly US, agricultural experts to this institution-building process was major, both by helping to identify the need in the 1950 s and by financing a set of institutional models in the 1960s.

\section{Recent World Bank Initiatives and Institution-Building}

As the green revolution in wheat began to reach its technical limits in the late 1970s, while in rice it seemed limited to Punjab, Himachal, Delhi and South India, agricultural progress had to be sought in other directions. Major avenues were irrigation and the quality of extension work. By this time, the lead was being taken, on the non-Indian side, not by the US government (as with CD) nor by US non-profit foundations (as with IADP), but by the World Bank, as both major lender and convener of the Aid-India Consortium. Recent Bank initiatives, in both irrigation and extension, have at tracted critics of their institutional aspect, who suggest that some of the faults evident in the CD programme in the 1950s reappear in these new formulations.

Since a major imperative of most aid agencies is to disburse large funds quickly, they are under pressure to identify quickly-replicable 'success stories' amongst their experimental projects. There is a danger, not always avoided, of failing to understand the determinants of the experimental success, and thus of building either wrong or inadequate components into the process of replication. There is, indeed, scepticism about whether a uniform set of components for widespread replication is sensible given the varied environmental conditions of Indian agriculture. These 
had required careful, locally specific adaptations of exotic high-yielding seeds; why not of institutions too?

The Bank's current emphasis is on rotational irrigation (Warabandi), outside the Northern 'wheat revolution' areas where it already operates (in preference to the existing method of continuous flow). Bank officers believed that such integrated water management had shown high returns in terms of additional grain yield over cost - making it an obvious candidate for replication - but required 'water users' associations'. Against this, Wade [1982: 177] has argued that the link between warabandi and the existence of a 'water users' association' is weak. In the pilot areas of warabandi, no such associations exist; the system works because the vigilance of individual farmers is strongly backed up by a bureaucratic authority. The insistence on the formation of users' associations seems to derive from an assumption that 'poor water management is caused by the negligence and uncooperativeness of the farmers', plus a hope that 'government itself need not become involved in such messy problems' as enforcing a water rotation. Thus, from an alleged misreading of existing irrigation institutions, there may be born a whole set of new irrigation institutions, existing on paper but essentially bogus.

The Bank's current agricultural extension reforms in India have met similar criticism. Moore (1984) notes that projects 'supported through foreign aid are subject to pressures for uniformity, rapid spread and an appearance of achievement [; these] militate against genuine institutional development, which requires time and adaptability'. Currently, the World Bank has been supporting the 'Training and Visit' ( $T$ and $V$ ) system, developed from pilot projects in India and Turkey in the 1970s. This involves freeing the villagelevel worker from non-extension duties, such as the supply and distribution of inputs; bringing him fully under the aegis of the Department of Agriculture (in non-IADP districts); putting heavy emphasis on training; and channelling this newly-acquired knowledge, via specific, simple weekly messages, through a minority of farmers, contacted according to a strict schedule of visits.

Moore implies that the Bank should have seen that the $T$ and $V$ system cut against the existing system of incentives (given that input supply was a source of informal income to those concerned with it), and was adopted, albeit partially, because it provided material inducements - new vehicles, promotions and larger budgets - for the senior cadres of the central and state departments of agriculture [Moore 1984: 311-4]. The extension agent lost informal income, was forced to switch departments, and was given a much tighter work schedule. $\mathrm{His}$ age and low educational attainments prevent him from seizing such opportunities for further training and upward mobility as have been provided. However, evidence from Haryana and Uttar Pradesh indicates that $T$ and $V$ is more effective at getting information to contact farmers, and at getting them to adopt new practices [Feder and Slade, 1984]. Clearly, the verdict is not yet in. Are the changes benefiting the farmers, and are they worth all the additional investment?

The disbursement imperative also affects bilateral aid to Indian agriculture. For example, a parliamentary review of the UK's bilateral programme observed:

In the case of British aid against the background of chronic underspending of the British aid budget, it is understandable that attempts should have been made to find projects which would disburse relatively large sums of money; and that deepening commitments are entered into to support these projects on the basis of inadequate appraisal [House of Commons 1979: xliii].

Nevertheless, it is a compliment to the Bank that its projects have been studied carefully. This happened because they are large, important and innovative, and because critical insights are often incorporated into the Bank's planning at the next round of development effort.

In both multilateral and bilateral programmes, one finds evidence of the phenomenon of 'meeting the target' [Tendler 1975: 85-107]. A shelf of projects which is too short leads aid agencies to act as if their capital is relatively abundant and must be committed quickly to justify further replenishment. Ill-prepared projects then inhibit successful institution-building and lead to unintended and undesired results. These then lead many commentators to conclude that institution-building via foreign aid is inherently impossible and should be abandoned. This is a great mistake. India over the years has furnished examples of eventual success (agricultural research), as well as partial failure (community development) and workin-progress (irrigation management, agricultural extension), where timely criticism can still lead to successful modification of an initial flawed design.

\section{What have we learned?}

The very question, 'can the Indian experience of aid, institution-building and rural development be usefully applied in sub-Saharan Africa?', invalidates the comic-opera account of adopting foreign paradigms. These are always inappropriate (the humour lies in the ways used by both donor and recipient to convince themselves, against their better judgement, that this is not so ) - but also virtually unavoidable in strategies 
for rapid, large-scale change. Thus the usefulness of a foreign model is correlated with the speed with which it is adapted as its initial bad consequences are discovered, not with its capacity to tolerate adherence against all odds.

The process of adaptation, in the Indian case, was additive or cumulative, rather than one of total or selective substitution. A longish period of experiment and disappointment preceded the moment when all the required elements for dramatic change came together effectively - at least in the most favoured agricultural areas. An intractable problem required a complex solution, involving administration, irrigation, new seeds, fertilisers, credit, insurance, economic incentives and so on. No single-factor solution was appropriate; yet a sequence of switching from, say, organisational change to price reform to new technical fixes would also have led nowhere.

India's experience makes one doubt the nostrums of today's Western governments and the ideologues of the World Bank's Research Department that Africa's food crisis can be solved by 'getting the prices right'. It is indeed important that input and output prices are such that producers are suitably rewarded. But this simple-minded approach neglects the problems of improving the elasticity of response of output to price change, which in a poor and rather hermetic [even if sophisticated: Richards 1985] agriculture means discovering and communicating massive technical changes that prove profitable even in the face of high risk [Lipton 1985a].

Indeed, the last missing ingredient in India's green revolution was locally-adapted variants of the new seeds. This underscores the importance of agricultural research institutes in defining the exact set of technical changes, required in particular places to increase price-elasticity of output. Although foreign funds cannot provide appropriate knowledge, they can help to supply the means by which it is produced. If there is one institution whose effective development should be a priority for foreign assistance, it is the national network of agricultural research institutes [Lipton 1985b]. Effective development, in the African context, is patently not the same as more spending. If, in Africa, research were focused on those crops which were chosen for attention in India in the late 1950s (maize, millet and sorghum), a good step would be made towards improved mass nutrition. Even more important are the major African roots and tubers (yams, cassava, cocoyams) because of their large calorie contribution to people's diets.

The presence of several high-quality agrarian research institutes would also be some guarantee against the lure of successful pilot projects. These have induced much false optimism, from Etawah to $T$ and V. The observed success is a compound of a 'pilot project effect', deriving from exceptional staff and the excitement of experiment; favourable circumstances of time or place, not typical outside the experimental area; and true, transferable success. Although rapid replication to a formula may be a poor policy, a foreign funding agency may well have its own imperatives for believing, or saying that it believes, otherwise. If there are also rewards in formula replication for the higher bureaucracy, they will be drawn into the collusion. The outcome will be a sham development which no-one has any interest in questioning, except the people at the bottom whose interests it was supposed to serve. And they may be too alienated or too powerless to protest.

\section{References}

Brown, D., 1971, Agricultural Development in India's Districts, Harvard University Press, Cambridge (Mass.)

Dasgupta, B., 1977, Agrarian Change and the New Technology in India, UNRISD, Geneva

Evenson, R. E. and Y. Kislev, 1976,Agricultural Research and Productivity, Yale University Press, New Haven

Feder, G. and R. Slade, 1984, 'A Comparative Analysis of Some Aspects of the Training and Visit System of Agricultural Extension in India' World Bank, Washington DC (mimeo)

Government of India, 1959, Report on India's Food Crisis and Steps to Meet $I t$, New Delhi

Hopper, W. D., 1976, Food Production in India, International Development Research Centre, Ottawa

House of Commons, 1979, The Pattern of United Kingdom Aid to India, First Report from the Select Committee on Overseas Development, Session 1978-79, HMSO, London

Krueger, A. O. and W. V. Ruttan, 1983, The Development Impact of Economic Assistance to LDCs, Vol. II, Ch 12 (mimeo)

Lipton, M., 1985a, 'Research and the Design of a Policy Frame for Agriculture', in T. Rose (ed.), Crisis and Recovery in sub-Saharan Africa, OECD Development Centre, Paris

$-1985 \mathrm{~b}$, The place of agricultural research in the development of sub-Saharan Africa', Discussion Paper 202, IDS, Sussex

Moore, M., 1984, 'Institutional development, the World Bank and India's New Agricultural Extension Programme', Journal of Development Studies, vol 20 no 4, July 
Packenham, R. A., 1973, Liberal America and the Third World, Princeton University Press

Richards, P., 1985, Indigenous Agricultural Revolution, Hutchinson, London

Rosen, G., 1985, Western Economists and Eastern Societies: Agents of Change in South Asia 1950-70, Oxford University Press, Delhi

Sussman, G. E., 1982, The Challenge of Integrated Rural Development in India: A Policy and Management Perspective, Westview Press, Boulder (Co.)

Tendler, J., 1975, Inside Foreign Aid, Johns Hopkins, Baltimore
Thorner, A., 1981, 'Nehru, Albert Mayer and Origins of Community Projects', Economic and Political Weekly, 24 January

Wade, R., 1982, 'The World Bank and India's Irrigation Reform', Journal of Development Studies, vol 18 no 2 , January

Wiser, W. H. and C. V. Wiser, 1971, Behind Mud Walls 1930-60. University of California Press, Berkeley, Los Angeles and London

Wolfson, J., 1976, Final Curtain: The Last Gilbert and Sullivan Operas, Chappell and Company/André Deutsch, London 